\title{
PHYTO-PHARMACOLOGICAL PROPERTIES OF SIDA CORDIFOLIA: A REVIEW OF FOLKLORE USE AND PHARMACOLOGICAL ACTIVITIES
}

\author{
NAVNEET KHURANA ${ }^{1 *}$, NEHA SHARMA ${ }^{1}$, SHAILENDRA PATIL ${ }^{2}$, ASMITA GAJBHIYE ${ }^{3}$
}

${ }^{1}$ Department of Pharmacology, School of Pharmaceutical Sciences, Lovely Professional University, Phagwara, Punjab, India. ${ }^{2}$ Department of Pharmaceutics, Sagar Institute of Pharmaceutical Sciences, Sagar, Madhya Pradesh, India. ${ }^{3}$ Department of Pharmaceutical Sciences, Dr. Hari Singh Gour Central University, Sagar, Madhya Pradesh, India. Email: navi.pharmacist@gmail.com

Received: 25 June 2016, Revised and Accepted: 02 July 2016

\section{ABSTRACT}

Plants have been considered to be useful as a medicine for treating different ailments and improving health conditions, since ancient times. The plants as herbal drugs lay down an important foundation of different, well recognized, ancient, and traditional healthcare systems in India as well as other parts of the world. In India, plants constitute an important and indispensable role in different ancient healthcare systems such as Ayurveda, Siddha, Unani, Naturopathy, and Homeopathy. In Ayurveda system of medicine, one of the Rasayana plants having a great medicinal importance is Sida cordifolia belonging to the family Malvaceae. It is an annual undershrub found throughout the tropical and subtropical regions of India. It has been used since ancient times for various ailments in Ayurveda system of medicine. It has numerous folklore uses in different pathological conditions. The plant also reported to possess a number of important pharmacological activities. The present review focused on all these folklore use of this herb along with its reported pharmacological activities.

Keywords: Sida cordifolia, Ayurveda, Parkinson's disease, Analgesic, Anti-inflammatory.

(C) 2016 The Authors. Published by Innovare Academic Sciences Pvt Ltd. This is an open access article under the CC BY license (http://creativecommons org/licenses/by/4. 0/) DOI: http://dx.doi.org/10.22159/ajpcr.2016.v9s2.13698

\section{INTRODUCTION}

Plants have always been considered to be one of the most important and indispensable sources of medicines, used for treating different pathological conditions, as well as for improving general human well-being. Their role has been well recognized since ancient times throughout the different parts of the world, including developing, as well as developed countries. According to the world health organization, about $80 \%$ or three quarters of the total world's population rely on the traditional plant-based medicines for their primary health care The plants considered to be an essential part of different ancient healthcare systems in India also which include Ayurveda, Siddha, Unani, Naturopathy, and Homeopathy system of medicines.

The health promotive, disease preventive and rejuvenation approach available in the Indian systems of medicine like "Ayurveda" is gaining greater attention and popularity in many regions of the world. This is a holistic approach of Ayurveda, which takes into consideration the whole body, mind, and spirit while dealing with the maintenance of health, promotion of health and treating ailments [1].

A number of Indian medicinal plants have been used for thousands of years in the Ayurveda system of medicine for various diseases. Sida cordifolia, belonging to the family Malvaceae, is considered to be an important medicinal plant belonging to the Rasayana category of Ayurvedic system of medicine. It is known with different names in different parts of the world. It is an annual undershrub found throughout the tropical and subtropical regions of India [2].

It has been reported to consist pharmacologically important phytoconstituents which include asparagine, quinazoline alkaloids, sympathomimetic amines, ephedrine, choline, betaine, rutin, phytosterol, $\beta$-sitosterol, hypaphorine, vasicinone, vascicine, vasicinol, and many others [3-6].

It has been used since ancient times for various ailments in Ayurveda. It has folklore us as a general tonic, anti-inflammatory agent, and blood coagulant. It has also been used in some gynecological practices, sexual inadequacies, and Parkinson's disease [7]. The leaves of the plant are reported to possess analgesic, anti-inflammatory [8], anticancer [9], diuretic, laxative, hypoglycemic, antispasmodic, antiamoebic, antiurinary filariasis, antiasthmatic, antihypertensive [10], and hepatoprotective [11] activities. Further, studies showed that aqueous fraction of hydroalcoholic extract of leaves induces vasorelaxation [12] hypotension, and bradycardia [13]. The plant was reported to have weight loss and wound healing, thyroregulatory, adaptogenic, antibacterial [14], antiplaque, and antifungal [15] activities. The plant was also reported to have antioxidant [16] and central nervous system (CNS) depressant [17] properties. Studies showed that the roots possessed diuretic and tonic properties and administered for nervous disorders such as hemiplegia and facial paralysis [18]. It is also reported to have a beneficial effect in different animal models Parkinson's disease $[19,20]$. As the plant processes numerous important pharmacological properties, so this study reviewed all these folklore use of this herb along with its reported pharmacological activities.

\section{TAXONOMIC HIERARCHY}

Kingdom: Plantae

Subkingdom: Tracheobionta

Super division: Spermatophyta

Division: Magnoliophyta

Class: Magnoliopsida

Subclass: Dilleniidae

Superorder: Malvanae

Order: Malvales

Family: Malvaceae

Subfamily: Malvoideae

Tribe: Malveae

Genus: Sida L.

Species: Sida cordifolia L.

Classical names

Sahadeva, Vatyalika, Vatyapushpi, Vatyayani.

Synonyms

Audanika, Badiyalaka, Baladhya, Balini, Bhadra, Bhadrabala, Bhadrodani, Brela, Jayanti, Kalyanini, Kanaka, Kathorayashtika, 
Kharakakashtika, Kharayashtika, Krura, Motapati, Nilaya, Odanavha, Odani, Odanika, Phanijivaka, Prahasa, Raktatandyla, Samanga, Samansha, Shitapaki, Suvarna, Svetberela, Variga, Vataghni, Vatyalaka, Vatyali, Vilala Maharamanga, Shotapaki, Sumangana, Vati, Vatyabhidhana, Vatyaha.

\section{Vernacular names}

English - Country mallow. Hindi - Kungyi, Bariyaar, Khiratee, Kharantee, Khareti, Barial, Bariar, Bariyara, Kharenti. Bengali - Swetberela, Brela, Bala, Bedela, Barila. Gujrati Mahabala, Khapat, Bala, Kharatee, Baladana, Janelimethi. Kannad - Hettuthi, Hettugigada, Kisangi, Chittuharalu. Malayalam - Kurunthott, Vellurum, Kathuram, Katturam. Marathi - Chikana, Khiranti. Punjabi - Kowar, Simak, kharent, kharyati, kharanhatee. Tamil - Nilatutti, Paniar-tuthi, Akhil mnapundu, Mayir manikham, Arivalmanaippundu. Telugu - Tellantisa, Tellagorra, Chiribenda, Suvarnamu, Muttav, Chitimutti, Tutturabenda. Oriya -Badianaula, Bisvokopari. Sindi - Burrayra. Mundari - Marang, Lupaaraba, Huringmindilata. Gwalior - Kharenti. Konkani - Kobirsirbhaji, Muttava. Sinhalese - Hiradona, Valbevila.

\section{BOTANICAL DESCRIPTION}

It is an annual or perennial short, erect, greyish-green, softly hairy or pubescent woody undershrub, 0.5-1 $\mathrm{m}$ high. Leaves are simple, very downy, alternate, $2.5-5 \mathrm{~cm} \times 1.8-3 \mathrm{~cm}$, orbicular, ovate, ovate-oblong or cordate, margin crenate, base cordate, petioled, stipulate, stipules linear. Flowers are bisexual, light or sulfur yellow to cream white, axillary and solitary but appears crowded in the upper part and toward tips of the branches, without an epicalyx. Fruits are depressed, globose schizocarp, 6-8 $\mathrm{mm}$ diameter, each carpel having two long straight linear to setaceous scabrous awns (Fig. 1). Seeds are smooth, flattened, reniform, brown or black. Flowering and fruiting generally happen from October to February month [2].

\section{DISTRIBUTION}

It is found throughout the tropical and subtropical regions of India up to an elevation of $1800 \mathrm{~m}$ in Himachal Pradesh. Bengal, Maharashtra, Madhya Pradesh, Gujarat, Andhra Pradesh, Assam, Jammu and Kashmir, Tamil Nadu, Uttar Pradesh, Coromandel, Karnataka, and Kerala are the chief regions of its occurrence [2].

\section{PHARMACOGNOSY}

Pattar and Jayaraj [21] performed the pharmacognostic and phytochemical investigations to determine the quality of $S$. cordifolia. This study comprised morphological, microscopical, and preliminary phytochemical investigations of the herb. Some of the pharmacognostic characters of this plant parts are discussed below.

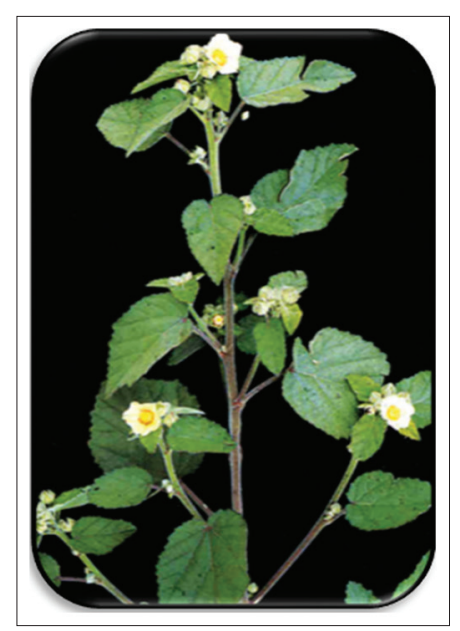

Fig. 1: Image of Sida cordifolia
Root

Macroscopy

Root occurs in variable sized pieces, 5-15 cm long with few lateral slender rootlets of smaller size, tap root branched at the tip; outer surface buff to grayish-yellow minutely striated or smooth; odorless; taste slightly bitter.

\section{Microscopy}

Transverse section is circular with a very wide central woody part and a thin outer bark. Cork consists of 4-6 rows of thin-walled, tangentially elongated cells, outer 1-2 rows light brown in color; phellogen consisting of single row, cortex very narrow comprising 3-4 rows of comparatively large polygonal or slightly tangentially elongated thinwalled cells, containing few clustered crystals of calcium oxalate and small starch grains [2]

\section{Stem}

\section{Macroscopy}

Stem occurs in variable sized pieces, cylindrical in shape, strong, dull green covered with stellate hairs, branches 2-3 mm thick, light brown or greenish gray in color, softly, hairy; fracture fibrous; odor no any specific odor; taste slightly bitter.

\section{Microscopy}

Transverse section circular in outline with stellate trichomes on epidermis followed by conspicuous zone of collenchyma, parenchyma, conducting elements and central pith. Epidermis is composed of oval to oblong, radially elongated, thin-walled cells covered by a thin cuticle. Trichomes are stellate or glandular. Epidermis followed by 1-2 layers of chlorenchyma followed by 4-6 layers of collenchyma consisting of round to oval cells [2].

Leaf

Macroscopy

They are 2-3 cm long, cordate, crenate, obtuse or sub-acute, hairy on both surfaces but more on the lower surface, nerves prominent on ventral surface, dorsal surface darker. Petiole hairy and shining brightly because of stellate hairs; fracture clear; odor no any specific odor; tasteless.

\section{Microscopy}

Transverse section of the leaf shows very thin cuticle with stellate and glandular trichomes on upper and lower epidermis. Stellate trichomes present on lower epidermis possess eight or more rays while those on upper epidermis consists of 5-6 rays. Stomata are anisocytic, average stomatal index of lower surface 27.03 while 22.4 at the upper surface. Single layered upper epidermis consists of oval to oblong cells followed by compactly arranged, rectangular elongated palisade cells, spongy parenchyma oval to round, and loosely arranged [2]

Physical constants of S. cordifolia are shown in Table 1.

\section{Thin layer chromatography (TLC)}

TLC of the methanol extract on precoated silica gel 60 plate $(5 \mathrm{~cm} \times 15 \mathrm{~cm})$ using chloroform: Methanol (7:3) and on spraying with anisaldehyde sulfuric acid reagent shows brown spot at Rf. 0.76 corresponding to ecdysterone and also shows five spots at Rf. 0.93 (violet), 0.89 (violet), 0.83 (blue), 0.15 (bluish green), and 0.06 (dark blue) [2].

Table 1: Physical constants of Sida cordifolia [2]

\begin{tabular}{llll}
\hline Constant & Root (\%) & Stem (\%) & Leaf (\%) \\
\hline Total ash & 6.69 & 9.73 & 15.62 \\
Acid insoluble ash & 2.74 & 2.43 & 7.57 \\
Alcohol soluble extractive & 2.78 & 2.86 & 4.51 \\
Water soluble extractive & 4.36 & 6.52 & 12.02 \\
\hline
\end{tabular}




\section{Phytochemical profile}

Ghosal et al. [4] isolated alkaloids from the roots of $S$. cordifolia. Three $\beta$-phenethylamines, viz., $\beta$-phenethylamine, ephedrine, and $\psi$-ephedrine; two carboxylated tryptamines, viz., S- $(+)-\mathrm{N}_{\mathrm{b}}-$ methyltryptophan methyl ester and hypaphorine; and three quinazoline alkaloids, viz., vasicinone, vasicine, and vasicinol were isolated from the plant. In addition, liberal amounts of choline and betaine have been obtained from the $\mathrm{H}_{2} \mathrm{O}$-soluble alkaloid fraction

Sutradhar et al. [22] investigated four new alkaloids of $S$. cordifolia, viz.; 1,2,3,9-tetrahydro-pyrrolo [2,1-b] quinazolin-3-ylamine, 5'-hydroxymethyl-1'-(1,2,3,9-tetrahydro-pyrrolo $[2,1-b]$ quinazolin-1-yl)-heptan-1-one,2-(1'-amino-butyl) indol-3-one, and 2'-(3H-indol-3-ylmethyl)-butane-1'-ol. All these four new alkaloids have been isolated from methanol extract of aerial parts of S. cordifolia and characterized using ${ }^{1} \mathrm{H}$ NMR, ${ }^{13} \mathrm{C}$ NMR, COSY, HMBC and mass spectra.

In another study conducted by Sutradhar et al. [23], authors isolated three new flavonol C-glycosides: 3'-(3",7"-dimethyl-2",6"octadiene)-8-C- $\beta$-D-glucosyl-kaempferol-3-0- $\beta$-D-glucoside, 3'-(3",7"-dimethyl-2",6"-octadiene)-8-C- $\beta$-D-glucosyl-kaempferol 3-0- $\beta$-D-glucosyl [1-4]- $\alpha$-D-glucoside, and 6-(3"-methyl-2"-butene)3 '-methoxyl-8-C- $\beta$-D-glucosyl-kaempferol 3-0- $\beta$-D-glucosyl [1-4]- $\beta$-Dglucoside from $80 \%$ ethanolic extract of the aerial parts of $S$. cordifolia Linn. followed by partitioning with ethyl acetate. Structures were established by chemical and spectroscopic methods.

In continuation to the previous study, Sutradhar et al. [24] also isolated and investigated two new bioactive flavones of 5,7-dihydroxy-3isoprenyl flavone and 5-hydroxy-3-isoprenyl flavone, along with two known compounds $\beta$-sitosterol and stigmasterol from the chloroform extract of $S$. cordifolia. Their structures were established on the basis of spectroscopic analysis. The chemical constituents, part wise are discussed below.

\section{Root}

Root contain $\mathrm{C}_{28}$ phytoecdysones, viz., sidasterone A, sidasterone $\mathrm{B}$ [5], carboxylated tryptamines, asparagine, quinazoline alkaloids, sympathomimetic amines, $\beta$-phenethylamine, $\psi$ ephedrine, choline, betaine, rutin, phytosterol, resin acids [4]. $\beta$-sitosterol acylsteryglycoside sitoindoside [5], ephedrine, [25], S- $(+)-\mathrm{Nb}$ methyltryptophan methylester, hypaphorine [3], vasicinone [26] vascicine, and vasicinol [6]. The roots contain $0.06 \%$ of alkaloid.

\section{Seed}

Seed contain proteins, steroids, resin, resin acid, mucin, phenethylamine, ephedrine, pseudoephedrine, fatty oil, potassium nitrate, linoleic acid, malvalic acid, sterculic acid, and coronaric acid [27]. The seeds contain $0.32 \%$ of alkaloid.

\section{Aerial parts}

Aerial parts contain palmitic, stearic, hexacosanoic acid $\beta$-sitosterol [28]. The aerial parts contain $0.31 \%$ and whole plant contains $0.085 \%$ of alkaloid.

\section{Uses in folklore and Ayurveda}

S. cordifolia roots, leaves, seeds, or whole plant have been used in the diseases of rakta pitta origin and is considered a healer of all malfunctions of the body. It is mainly used for following conditions [7].

\section{As a general tonic}

It is being used for nervous debility, loss of memory, virility and as an aphrodisiac. In general weakness, it is said to protect the inner vital energy of the body ojas and keep away old age. The herbs are well esteemed for strengthening the urogenital systems of both males and females. These help sexual inadequacies and infectious diseases, particularly those transmitted sexually [7].

\section{In gynecological practices}

It has been used in threatened abortion and strengthens placental retention in expectant mothers. As per ayurvedic concept, leukorrhea in females develops due to weakness in the body. One teaspoonful of fine $S$. cordifolia powder prescribed twice daily provides the desired strength. In the case of inflammation of the ovary, a compound preparation of $S$. cordifolia along with Balaydighrit is given to the mother and to the newborn infant [7].

\section{As an anti-inflammatory agent}

For suppuration of boils formed from pus, a poultice of tender leaves is applied to the boils. Cold water is sprinkled on occasionally. In this way, the boil bursts without surgery. The juice of the bark is considered to have anti-inflammatory activity and is used in urtica, scorpion sting, etc. In burning micturition and polyurea, a fine powder of root and seed with ghee and sugar reduces inflammation. In hoarseness of voice caused by too much cold, singing or crying loudly, half a spoon of $S$. cordifolia powder with honey clears the throat. The decoction of the root gives relief to alcoholics, who feel dryness of mouth, excessive thirst and burning sensation in the throat after consuming alcohol [7]

\section{As a blood coagulant}

In bleeding piles, where blood is passed with feces and the problem is aggravated by indigestion and constipation, $10 \mathrm{~g}$ of $S$. cordifolia powder, boiled with $80 \mathrm{ml}$ of water until reduced to $20 \mathrm{ml}$ is strained. One cup of milk is added to the filtrate. This mixture is taken in the morning. It not only helps with hemorrhoids but also coagulates blood in the other parts of the body, such as nose and mouth [7].

\section{In sexual inadequacies}

In males, 5-6 g of root powder in the morning on an empty stomach increases the viscosity of semen and prevents its involuntary discharge. In swollen testes, a decoction of $S$. cordifolia, 4 teaspoons along with 2 teaspoons of castor oil, is prescribed [7].

\section{In Parkinson's disease}

It is reported in the ancient ayurvedic literature that $S$. cordifolia powder can be administered for nervous disorders such as hemiplegia, facial paralysis [18] and for the treatment of Parkinson's disease [29]. It is used as a prime herb along with Mucuna pruriens and Withania somnifera for balancing the disturbed vata in Parkinson's disease.

\section{Pharmacological activities}

In the previous studies, $S$. cordifolia has been reported to have numerous indications in different pathological conditions. A number of reviewers have reviewed and highlighted the traditional uses, ayurvedic preparation, chemical constituents, and pharmacological properties of S. cordifolia. It has been used to treat bronchial asthma, cold and flu, chills, lack of perspiration, head ache, nasal congestion, aching joints and bones, cough and wheezing, and edema. The root infusion is given in nervous and urinary diseases and also in disorders of the blood and bile [30]. Reviewers also reviewed the wide variety of therapeutic and pharmacological uses of this plant like analgesic, anti-inflammatory, antistress, antidiabetic, anticancer activity, as well as hepatoprotective activity. It has also been used as CNS depressant, fat loss, hypotensive agent. It is used in various ayurvedic preparation for the different conditions $[31,32]$

Due to all of these properties, this plant is one of the cornerstones in ethnopharmacology and ethnobotanical sciences. Pharmacological screening of botanicals is necessary for viewing new chemical entities, which is designed to search for novel drug actions at an early stage of drug development and below mentioned activities review the highlights about all these pharmacological activities of S. cordifolia. 


\section{Anti-oxidant activity}

Auddy et al. [16] screened the antioxidant activity of three Indian medicinal plants; S. cordifolia, Cynodon dactylon, Evolvulus Alsinoides, traditionally used for the management of neurodegenerative diseases and found that water infusion and ethanolic extract of all the three Rasayana plants have antioxidant activity tested by two methods; 2,2'-azinobis-3-ethyl-benzothiazoline-6-sulfonic acid $\left(\mathrm{ABTS}^{+}\right)$radical cation decolorization assay and inhibition of lipid peroxidation of rat brain homogenate by plant infusions. All these plants were found to have significant antioxidant activity in all the above-mentioned tests. All the three plant infusions were also tested for the viability of pheochromocytoma (PC12) cell line as judged by 3-(4,5-dimethylthiazol-2-yl)-2,5-diphenyltetrazolium bromide test and showed no toxic effects.

\section{Activity against Parkinson's disease}

Nagashayana et al. [29] studied the association of levodopa with recovery following Ayurveda medication in Parkinson's disease. In a clinical prospective study, the authors have evaluated the efficacy of Ayurveda treatment (a concoction in cow's milk of powdered M. pruriens and Hyoscyamus reticulatus seeds and W. somnifera and S. cordifolia roots) in 18 clinically diagnosed (with a mean Hoen and Yahr value of 2.22) Parkinsonian patients. The study established the necessity of cleansing therapy in Ayurveda medication prior to palliative therapy. It also revealed the contribution of levodopa in the recovery as observed in Parkinson's disease following ayurveda medication.

In a study conducted by Khurana et al. [20], authors evaluated the reversal effect of $S$. cordifolia in reserpine-induced orofacial dyskinesia and catalepsy in rats. They investigated the effect of aqueous and hydroethanolic extracts of S. cordifolia (AESC and EESC) respectively, in reserpine-induced orofacial dyskinesia and catalepsy along with lipid peroxidation evaluated by the levels of thiobarbituric acid like reactive substances (TBARS) in rat forebrain. Repeated administration of reserpine ( $1 \mathrm{mg} / \mathrm{kg}$; s.c.) on alternate days (day 1, 3 and 5) for a period of 5-day significantly increased the vacuous chewing movements, tongue protrusions, orofacial bursts, and catalepsy along with increased forebrain TBARS levels in rats which was dose-dependently reversed by AESC (50, 100 and $250 \mathrm{mg} / \mathrm{kg}$; p.o.) treatment. No significant effect on these behavioral parameters was observed following varying dose (50, 100 and $250 \mathrm{mg} / \mathrm{kg}$; p.o.) treatment of EESC in reserpine-treated rats. These findings suggested the involvement of antioxidant activity along with other underlying mechanisms for the ameliorative effect of AESC in reserpine-induced orofacial dyskinesia and catalepsy. This study predicted the scope of aqueous of $S$. cordifolia in the possible treatment of neuroleptic-induced orofacial dyskinesia and Parkinson's disease.

In another study conducted by Khurana and Gajbhiye [19], ameliorative effect of S. cordifolia in rotenone-induced oxidative stress model of Parkinson's disease has been evaluated. In this study, they evaluated the effect of AESC and its different fractions; hexane (HFSC), chloroform (CFSC) and aqueous (AFSC), against rotenone-induced biochemical, neurochemical, histopathological and behavioral alterations in a rat model of Parkinson's disease. An estimation of the level of TBARS, glutathione (GSH),and catalase (CAT) along with superoxide anion generation (SAG) in different brain regions (cortex, midbrain, and cerebellum) was carried out to assess biochemical changes. Behavioral evaluation tests (catalepsy, rearing behavior and posture instability) and neurochemical estimations (norepinephrine, dopamine, and serotonin level) along with histopathological evaluations of different brain regions were also performed. The varying doses $(50,100,250 \mathrm{mg} / \mathrm{kg}$; p.o.) of different test treatments (AESC, HFSC, CFSC and AFSC) were coadministered along with rotenone $(2 \mathrm{mg} / \mathrm{kg}$; s.c.), for a period of 35 -day to rats of various groups and compared with rotenone per se (negative control) and L-deprenyl (positive control; $10 \mathrm{mg} / \mathrm{kg}$; p.o.) treated groups for the above mentioned parameters. The increase in catalepsy and posture instability along with a decrease in rearing behavior observed due to rotenone treatment was significantly attenuated by co-treatment with varying doses of AESC and AFSC. Results of the histopathological studies of different brain regions of rats showed eosinophilic lesions in the midbrain region due to rotenone treatment. The eosinophilic lesions were significantly attenuated in co-treated groups of AESC- $100 \mathrm{mg} / \mathrm{kg}$ and AFSC-100 mg/kg. Rotenone-induced oxidative damage, revealed by increased level of TBARS, SAG and decreased level of GSH and CAT in midbrain region of rats, was attenuated by the co-treatment of AESC and AFSC. The rotenone-induced decrease of dopamine level in the midbrain region of rats was also attenuated by co-treatment of AESC- $100 \mathrm{mg} / \mathrm{kg}$ and AFSC- $100 \mathrm{mg} / \mathrm{kg}$. The maximum effect in all the above activities was observed in AFSC $(100 \mathrm{mg} / \mathrm{kg})$ treated group, which was comparable to L-deprenyl treated group. The HFSC and CFSC co-treatment failed to show significant attenuation of rotenone-induced damage. These results indicated the possible therapeutic potential of the most polar fraction of AESC, i.e., AFSC in Parkinson's disease by virtue of its antioxidative actions [19].

\section{CNS depressant activity}

Franco et al. [17] studied the CNS pharmacological effects of hydroalcoholic extract of $S$. cordifolia leaves and reported that the extract showed low toxicity at higher doses in the test for determination of lethal dose $\left(\mathrm{LD}_{50}\right)$. Depressive activity on CNS was demonstrated by several alterations in mice's behavior in the pharmacological screening. In the motility test, the extract showed significant reduction of spontaneous activity. The extract also decreased the ambulation and rearing in open-field test.

\section{Antifertility activity}

Pokale and Kulkarni [33] evaluated the antifertility potential of aqueous extract of Sida cardifolia Linn. in Swiss albino mice. The treatment caused decrease in weight of ovaries and uterus, which supports its antifertility activity. Results of the histological examination performed in this study also support its antifertility activity.

\section{Anthelmintic activity}

Pawa et al. [34] performed the in vitro studies on ethanolic and aqueous extract of whole plant $S$. cordifolia Linn. for anthelmintic and antioxidant properties. The antioxidant activities were evaluated by various antioxidant assays like $\alpha, \alpha$-Diphenyl- $\beta$-picrylhydrazyl free radical scavenging, total reducing power, nitric oxide scavenging and hydrogen peroxide scavenging. The antioxidant activity of the ethanolic extract was almost quantitatively equivalent to that of the standards used, ascorbic acid. The further anthelmintic activity of the whole plant, investigated using Indian earthworm (Pheretima posthuma) showed that it is one of the most important local medicinal plants both for ritual and ethnomedical practices. The results indicated that S. cordifolia Linn. possesses potent antioxidant and anthelmintic activity.

\section{Antibacterial activity}

Kalaiarasan and John [35] performed the phytochemical screening and antibacterial investigation of $S$. cordifolia $\mathrm{L}$. leaf extract. The ethanol and methanol extracts revealed the presence of alkaloids, glycosides, carbohydrates, flavonoids, phenols, saponins, and tannins. The results of the antibacterial activity studied using agar-disc diffusion method showed that both extracts inhibit the growth, in selected organisms, i.e., Escherichia faecalis, Escherichia coli, Pseudomonas aeruginosa.

\section{Activity against myocardial injury}

Kubavat and Asdaq [36] studied the role of hydroalcoholic extract of $S$. cordifolia $\mathrm{L}$. leaves on biochemical and antioxidant profile during myocardial injury in rats. They found the protective effect of $S$. cordifolia on heart injury, as evaluated by endogenous biomarkers (lactate dehydrogenase and creatine kinase isoenzyme) and antioxidants levels (superoxide dismutase assay and CAT), estimated in serum/perfusate and heart tissue homogenate. Moreover, biochemical findings were supported by histopathological observations. The result of the study confirmed, at least in part, for the use of $S$. cordifolia in folk medicine to treat myocardial injury. 


\section{Hypotensive and bradycardia effects}

Silveira et al. [37] evaluated the cardiovascular effects of vasicine, an alkaloid isolated from the leaves of S. cordifolia L. The results of the study showed that vasicine produced hypotension and bradycardia which appeared to be due to the stimulation of cardiac muscarinic receptors (directly and/or indirectly), and by a decrease of the peripheral resistances.

In a study conducted by Santos et al. [38] investigated the cardiovascular effects on unanesthetized normotensive rats induced by the total alkaloid fraction of $S$. cordifolia and observed induction of hypotension and bradycardia, which appear to be mediated by direct and indirect activation of muscarinic receptors. Nitric oxide also appears to be involved in the hypotensive response.

Medeiros et al. [13] also studied the cardiovascular effect of the aqueous fraction of the hydroalcoholic extract of $S$. cordifolia leaves and reported that the extract produces hypotension and bradycardia which is mainly due to a direct stimulation of the endothelial vascular muscarinic receptor and indirect cardiac muscarinic activation, respectively.

\section{Hypolipidemic activity}

Asdaq et al. [39] studied the effect of hydroalcoholic extracts of $S$. cordifolia leaves on lipid profile in rats and reported that that the chronic administration of the extract in high dose has definite cardioprotective potential, which was determined by serum levels of total cholesterol, triglyceride, low-density lipoprotein cholesterol, high-density lipoprotein cholesterol, aspartate aminotransferase, and alanine aminotransferase. These results constitute a valid scientific basis for consuming S. cordifolia for medicinal application.

\section{Analgesic and anti-inflammatory activity}

Franzotti et al. [8] studied the anti-inflammatory, analgesic activity and acute toxicity of an aqueous extract of $S$. cordifolia in animal models. The aqueous extract showed a significant inhibition of carrageenininduced rat paw edema after oral administration but did not block the edema induced by arachidonic acid. It also increased the latency period for mice in the hot plate test and inhibited the number of writhes produced by acetic acid. The aqueous extract of $S$. cordifolia showed low acute toxicity in mice.

In a study conducted by Sutradhar et al. [40], analgesic and antiinflammatory activities of a new bioactive alkaloid (5'-Hydroxymethyl1'-(1,2,3,9-tetrahydro-pyrrolo [2,1-b] quinazolin-1-yl)-heptan-1-one) (compound 1), isolated from S. cordifolia Linn, were evaluated. The analgesic activity was investigated in the acetic acid induced writhing and the radiant heat tail-flick model in mice and the carrageenaninduced rat paw edema model was used for the anti-inflammatory study. The results of the study indicated that compound 1 possessed analgesic and anti-inflammatory activities.

In another study by Sutradhar et al. [24], authors isolated and investigated two new bioactive flavones of 5,7-dihydroxy-3-isoprenyl flavone and 5-hydroxy-3-isoprenyl flavone, along with two known compounds $\beta$-sitosterol and stigmasterol from the chloroform extract of $S$. cordifolia. Flavones were tested and shown significant analgesic and anti-inflammatory activity.

Momin et al. [41] performed the phytochemical screening (group determination) and selected pharmacological activities (antioxidant, antimicrobial, and analgesic activity) evaluation of the plant S. cordifolia Linn. $80 \%$ concentrated ethanol extract of the roots was used. Phytochemical screening of the crude extract indicated the presence of reducing sugar, alkaloids, steroids, and saponins. In diphenylpicrylhydrazyl scavenging assay, the half maximal inhibitory concentration (IC50) value was found to be $50 \mu \mathrm{g} / \mathrm{ml}$ which was not comparable to the standard ascorbic acid. The crude extract produced $44.30 \%$ inhibition of writhing at the dose of $500 \mathrm{mg} / \mathrm{kg}$ body weight which is statistically significant. The in vitro antimicrobial activity of extract showed no activity against five types of microorganisms.

\section{Anti-pyretic and anti-ulcerogenic activity}

Philip et al. [42] studied the anti-pyretic and anti-ulcerogenic properties of methanolic extract of S. cordifolia aerial parts in rats and showed that the extract significantly reduced pyrexia induced by $T A B$ vaccine. The extract exhibited significant antiulcerogenic effect against aspirin and ethanol-induced damage. Both these properties were comparable to the reference drugs.

\section{Anti-diabetic activity}

Kanth and Diwan et al. [10] studied hypoglycemic, analgesic and antiinflammatory activities with aerial and roots of $S$. cordifolia extracts and found to have anti-diabetic properties. Mahrukh et al. [43] evaluated hypoglycemic, anti-hyperlipidemic, and antioxidant potential of alcoholic extract of S. cordifolia at a dose of (200 and $400 \mathrm{mg} / \mathrm{kg}$ ) in streptozotocin-induced diabetes rats at the dose of $55 \mathrm{mg} / \mathrm{kg}$. At a dose of $400 \mathrm{mg} / \mathrm{kg} \mathrm{S}$. cordifolia extracts showed significant reduction of the blood glucose level in diabetic rats and there was a decrease in total cholesterol, triglycerides, low-density lipid, plasma creatine, plasma-urea nitrogen. There was a significant increase observed in this study in antioxidant enzymes such as CAT and superoxide-dismutase activity.

\section{Nephroprotective activity}

Bhatia et al. [44] observed that treatment with both ethanolic and aqueous extracts of $S$. cordifolia Linn. showed nephron protective activity when compared to gentamicin. Due to the potent antioxidant activity, S. cordifolia might have exhibited its nephron protective activity. Mehul et al. [45] studied effect of $S$. cordifolia, as nephron protective agent, using aqueous extract at a dose level of $200 \mathrm{mg} / \mathrm{kg}$ and $400 \mathrm{mg} / \mathrm{kg}$ concentrations against gentamycin $(100 \mathrm{mg} / \mathrm{kg})$ and cisplatin $(7 \mathrm{mg} / \mathrm{kg})$ as inducing agents. In this study, authors attributed its protective effect to the flavonoids and phenols present in this plant which contributes for antioxidant effects and exhibits nephroprotective activity.

\section{Antistress and adaptogenic activity}

Sumanth and Mustafa [46] demonstrated about the adaptogenic activity in S. cordifolia Linn. The extracts were prepared and administered orally in rats. Ashwagandha which was in water-soluble powder form was used as reference standard. The result showed that $S$. cordifolia extracts reduced plasma cortisol level as well as blood glucose.

\section{Anticancer and cytotoxic activity}

Matsui et al. [9] previously established a bioassay method to screen for compounds that activate the promoter activity of p21WAF1/CIP1, a potent inhibitor of cyclin-dependent kinases, in a p53-independent manner. As an activator of p21WAF1/CIP1 promoter activity, authors isolated cryptolepine (CLP: 5-methyl indolo (2,3b)-quinine), an indoloquinoline alkaloid, from the traditional ayurvedic medicinal plant S. cordifolia. They showed here that CLP-induced the expression of p21WAF1/CIP1 with growth arrest in p53-mutated osteosarcoma human osteosarcoma cell line (MG63 cells). The results of the study raised the possibility that CLP might be a suitable chemotherapeutic agent for the treatment of osteosarcoma.

Joseph et al. [47] conducted a study to identify the bioactive compounds from the $S$. cordifolia plant and observe its cytotoxic effect on Hela cell lines. The results from gas chromatography-mass spectrometry analysis showed mainly four different compounds such as vasicinol, ephedrine, vasicinone, and hypaphorine based on retention time and peak observation. The results of cytotoxic activity on Hela cells treated with $S$. cordifolia extracts showed that cells with uncontrolled growth have been arrested and there is decline level of cancerous cells. 


\section{Hepatoprotective activity}

Rao and Mishra [48] studied the hepatoprotective activity of S. cordifolia powdered roots, aerial parts and their extracts against carbon tetrachloride, paracetamol, and rifampicin-induced hepatotoxic rats. It was observed that the powdered aerial and root parts showed a significant hepatoprotective activity against carbon tetrachloride followed by methanolic and aqueous extracts. Rejitha et al. [49] studied the hepatoprotective activity of $50 \%$ ethanolic extract of the roots of $S$. cordifolia L against alcohol intoxication model. Alcoholinduced toxicity is mediated through oxidative stress and it can be monitored by detecting lipid peroxidation products. Malondialdehyde, hydroperoxides, and conjugated dienes were significantly reduced in liver and protein carbonyls in the serum which was observed in the rats that were administered with ethanolic extracts of $S$. cordifolia. The mRNA level of cytochrome P450 2E1, nuclear factor- $\kappa \mathrm{B}$, tumor necrosis factor alpha and transforming growth factor- $\beta$ were found to be increased in the alcohol treated rats and their expressions were found to be decreased in the $S$. cordifolia extracts treated rats. Silva et al. [11] also assessed the effects of the aqueous extract of $S$. cordifolia leaves, on liver regeneration after partial hepatectomy. The results showed that the extract stimulates liver regeneration after $67 \%$ partial hepatectomy in rats.

\section{Toxicology}

Aqueous extracts of leaves showed low acute toxicity in mice [8]. $\mathrm{LD}_{50}$ value was higher than $10 \mathrm{~g} / \mathrm{kg}$ in rats [50]. The hydroalcoholic extract of leaves was found to be toxic at high i.p. doses. The $\mathrm{LD}_{50}$ values were $2639 \mathrm{mg} / \mathrm{kg}$ with $95 \%$ confidence limits of $2068-3367 \mathrm{mg} / \mathrm{kg}$ for i.p. administration [17].

\section{Therapeutic evaluation}

In a clinical prospective study, the efficacy of Ayurveda treatment (a concoction in cow's milk of powdered M. pruriens, $H$. reticulatus seeds, W. somnifera, and S. cordifolia roots) in 18 clinically diagnosed parkinsonian patients was evaluated. As per ayurvedic principles, 13 patients underwent both cleansing (for 28 days) and palliative therapy (56 days), 5 patients underwent palliative therapy alone (84 days). Only the former group showed significant improvement in activities of daily living and on motor examination as per unified Parkinson's disease rating scale. Symptomatically, they exhibited better response in tremor, bradykinesia, stiffness and cramps as compared to the latter group. Excessive salivation worsened in both the groups. Analyses of powdered samples in milk, as administered in patients, revealed about $200 \mathrm{mg}$ of levodopa per dose. The study establishes the necessity of cleansing therapy in Ayurveda medication prior to palliative therapy. It also reveals contribution of levodopa in the recovery as observed in Parkinson's disease following Ayurveda medication [29].

\section{CONCLUSION}

As plants are considered to be one of the most important sources of medicines, exploration of therapeutically potential candidates from the herbal origin for various ailments is always considered to be an important path of developing new therapeutic strategies. S. cordifolia plant, which is widely distributed in India, is a plant having a wide range of reported activities along with the support of its traditional folklore use in the various pathological conditions. This review discussed all these therapeutically potential activities of this medicinally important plant and thus put light on the scope of this plant for the future development of therapeutic lead for various ailments. This review also opens the scope of exploration of other untapped pharmacological activities of this plant, which are yet unexplored.

\section{REFERENCES}

1. Ghanekar BG. Sutrasthana. In: Sushrut Samhita. Varanasi: Motilal Banarasidas; 1981. p. 3.

2. Chandra K, Chaudhari BG, Dhar BP, Joseph JV, Mangal AK, Dabur R, et al. Database on medicinal plants used in Ayurveda. Cent Counc Res Ayurveda Siddha 2007;8:42-58.
3. Ghosal S, Banerjee PK, Banerjee SK. A general method for the isolation of naturally occurring water-soluble bases. Phytochemistry 1970;9(2):429-33.

4. Ghosal S, Ballav R, Chauhan PS, Mehta R. Alkaloids from Sida cordifolia. Phytochemistry 1975;14:830-2.

5. Ghosal S, Kaur R, Bhattacharya SK. Chemistry and bioactivity of sitoindosides IX and X. Planta Med 1988;54(6):561.

6. Bhatnagar AK, Bhattacharji S, Popli SP. On the identity of vasicinol. Indian J Chem 1965;3:524.

7. Puri HS. 'Rasayana' - Ayurvedic Herbs for Longevity and Rejuvenation. Vol. 8. London: Taylor and Francis; 2003. p. 64-70.

8. Franzotti EM, Santos CV, Rodrigues HM, Mourão RH, Andrade MR, Antoniolli AR. Anti-inflammatory, analgesic activity and acute toxicity of Sida cordifolia L. (Malva-branca). J Ethnopharmacol 2000;72(1-2):273-7.

9. Matsui TA, Sowa Y, Murata H, Takagi K, Nakanishi R, Aoki S, et al. The plant alkaloid cryptolepine induces p $21 \mathrm{WAF} 1 / \mathrm{CIP} 1$ and cell cycle arrest in a human osteosarcoma cell line. Int J Oncol 2007;31(4):915-22.

10. Kanth VR, Diwan PV. Analgesic, antiinflammatory and hypoglycaemic activities of Sida cordifolia. Phytother Res 1999;13(1):75-7.

11. Silva RL, Melo GB, Melo VA, Antoniolli AR, Michellone PR, Zucoloto S, et al. Effect of the aqueous extract of Sida cordifolia on liver regeneration after partial hepatectomy. Acta Cir Bras 2006;21 Suppl 1:37-9.

12. Santos MR, Nascimento NM, Antoniolli AR, Medeiros IA. Endothelium-derived factors and $\mathrm{k}$ channels are involved in the vasorelaxation induced by Sida cordifolia L. In the rat superior mesenteric artery. Pharmazie 2006;61(5):466-9.

13. Medeiros IA, Santos MR, Nascimento NM, Duarte JC. Cardiovascular effects of Sida cordifolia leaves extract in rats. Fitoterapia 2006;77(1):19-27.

14. Alam M, Joy S, Ali US. Antibacterial activity of Sida cordifolia Linn, Sida rhomboidea Roxb and Triumfetta rotundifolia lam. Indian Drugs 1991;28(12):570-2.

15. Muauza DN, Kim BW, Euler KI, Williams L. Pharmacognostic studies of Sida cordifolia. Int J Pharmacog 1994;32:334.

16. Auddy B, Ferreira M, Blasina F, Lafon L, Arredondo F, Dajas F, et al. Screening of antioxidant activity of three Indian medicinal plants, traditionally used for the management of neurodegenerative diseases. J Ethnopharmacol 2003;84(2-3):131-8.

17. Franco CI, Morais LC, Quintans-Júnior LJ, Almeida RN, Antoniolli AR. CNS pharmacological effects of the hydroalcoholic extract of Sida cordifolia L. leaves. J Ethnopharmacol 2005;98:275-9.

18. Rastogi RP, Malhotra BN. Compendium of Indian Medical Plants. Vol. 4. Lucknow: Drug Research Institute; 1985. p. 674.

19. Khurana N, Gajbhiye A. Ameliorative effect of Sida cordifolia in rotenone induced oxidative stress model of Parkinson's disease. Neurotoxicology 2013;39:57-64.

20. Khurana N, Jain PK, Pounikar Y, Patil S, Gajbhiye A. Reversal of reserpine-induced orofacial dyskinesia and catalepsy by Sida cordifolia. Int J Pharmacol Pharm Tech 2012;1(2):121-5.

21. Pattar PV, Jayaraj M. Pharmacognostic and phytochemical investigation of Sida cordifolia L. A threatened medicinal herb. Int J Pharm Pharm Sci 2012;4(1):114-7.

22. Sutradhar RK, Rahman AK, Ahmad MU, Saha K. Alkaloids of Sida cordifolia L. Indian J Chem 2007a;46:1896-900.

23. Sutradhar RK, Rahman AK, Ahmad MU. Three new flavonol C glycosides from Sida cordifolia Linn. J Iran Chem Soc 2007b;4(2):175-81.

24. Sutradhar RK, Rahman AK, Ahmad MU, Bachar SC. Bioactive flavones of Sida cordifolia. Phytochem Lett 2008;1(4):179-82.

25. Begerhotta A, Bannerjee N. Polarographic studies on active constituents of Sida cordifolia. Curr Sci 1985;54:690.

26. Mehta DR, Nawane JS, Desai RM. Vasicinone, a bronchodilator principle of Adhatoda Vasica Nees. J Org Chem 1963;28(2):445.

27. Farooqui MY, Ahmed AE. Chemistry of essential oil of Sida cordifolia. Chem Ind 1985;14:483.

28. Khan MW, Rashid MA, Huq E, Ahmad MU. The non-polar constituents of Sida cordifolia Linn. J Bangladesh Acad Sci 1989;13:55-60.

29. Nagashayana N, Sankarankutty P, Nampoothiri MR, Mohan PK, Mohanakumar KP. Association of L-DOPA with recovery following Ayurveda medication in Parkinson's disease. J Neurol Sci 2000;176(2):124-7.

30. Jain A, Choubey S, Singour PK, Rajak H, Pawar RS. Sida cordifolia (Linn) - An overview. J Appl Pharm Sci 2011;1(2):23-31.

31. Mallikarjuna G, Prabhakaran V, Sree Lakshmi K. Pharmacological 
activities of Sida cordifolia: A review. Int J Phytopharmacol 2013;4(5):315-21.

32. Srinithya B, Muthuraman MS. An overview on the biologica perspectives of Sida cordifolia Linn. Int J Pharm Pharm Sci 2014;6(11):15-7.

33. Pokale S, Kulkarni K. Evaluation of antifertility potential of aqueous extract of Sida cardifolia Linn. Plant in swiss albino mice. Int J Pharm Pharm Sci 2012;4(2):128-31.

34. Pawa RS, Jain A, Sharma P, Chaurasiya PK, Singour PK. In vitro studies on Sida cordifolia Linn for anthelmintic and antioxidant properties. Chin Med 2011;2:47-52.

35. Kalaiarasan A, John SA. Phytochemical screening and antibacteria activity of Sida cordifolia L. (Malvaceae) leaf extract. Int J Med Res 2010;1(2):94-8.

36. Kubavat JB, Asdaq SM. Role of Sida cordifolia L. Leaves on biochemica and antioxidant profile during myocardial injury. J Ethnopharmacol 2009;124(1):162-5.

37. Silveira AL, Gomes MA, Filho S, Santos RN, Medeiros MR, Barbosa FJ. Evaluation of the cardiovascular effects of vasicine, an alkaloid isolated from the leaves of Sida cordifolia L. (Malvaceae). Rev Bras Farmacogn 2003;13(2):37-9.

38. Santos MR, Marchioro M, Silveira AL, Filho JM, Medeiros IA Cardiovascular effects on rats induced by the total alkaloid fraction of Sida cordifolia. Biol Geral Exper 2005;5(2):5-9.

39. Asdaq SM, Nayeem N, Das AK. Effect of hydroalcoholic extracts of Sida cordifolia L. Leaves on lipid profile in rats. Pharmacologyonline 2008;3:227-39.

40. Sutradhar RK, Rahman AK, Ahmad MU, Bachar SC, Saha A, Guha SK. Bioactive alkaloid from Sida cordifolia Linn. With analgesic and antiinflammatory activities. Iran J Pharmacol Ther 2006;5(2):175-8.
41. Momin MA, Bellah SF, Rahman SM, Rahman AA, Murshid GM, Emran TB. Phytopharmacological evaluation of ethanol extract of Sida cordifolia L. Roots. Asian Pac J Trop Biomed 2014;4(1):18-24.

42. Philip BK, Muralidharan A, Natarajan B, Varadamurthy S, Venkataraman S. Preliminary evaluation of anti-pyretic and antiulcerogenic activities of Sida cordifolia methanolic extract. Fitoterapia 2008;79(3):229-31.

43. Ahmad M, Prawez S, Sultana M, Raina R, Pankaj NK, Verma PK, et al. Anti-hyperglycemic, anti-hyperlipidemic and antioxidant potential of alcoholic-extract of Sida cordifolia (areal part) in streptozotocininduced-diabetes in wistar-rats. Proc Natl Acad Sci 2014;84(2):397-405.

44. Bhatia L, Bhatia V, Grover M. Nephroprotective effect of fresh leaves extracts of Sida cordifolia Linn in gentamicin induced nephrotoxicity in rats. Int J Res Pharm Sci 2012;2(2):151-8.

45. Mehul V, Makwana, NM, Pandya D, Darji N, Sarav AD. Assessment of nephroprotective potential of Sida cordifolia Linn. In experimental animals. Sch Res Libr 2012;4(1):175-80.

46. Sumanth M, Mustafa SS. Antistress, adoptogenic activity of Sida cordifolia roots in mice. Indian J Pharm Sci 2009;71(3):323-4.

47. Joseph B, Ajisha AU, Satheesna K, Sujatha S. Effect of bioactive compounds and its pharmaceutical activities of Sida cordifolia (Linn.). Int J Biol Med Res 2011;2(4):1038-42.

48. Rao KS, Mishra SH. Isolation and assessment of hepatoprotective activity of fumaric acid obtained for the first time from Sida cordifolia Linn. Indian Drugs 1997;34(12):702-6.

49. Rejitha S, Prathibha P, Indira M. Amelioration of alcohol-induced hepatotoxicity by the administration of ethanolic extract of Sida cordifolia Linn. Br J Nutr 2012;108(7):1256-63.

50. Rao KS, Mishra SH. Antihepatotoxic activity of Sida cordifolia whole plant. Fitoterpia 1998;69(1):20-33. 